\title{
Electrochemical Detection of $\mathrm{Pb}$ and $\mathrm{Cd}$ in Paper-Based Microfluidic Devices
}

\author{
Jianjun Shi, ${ }^{a}$ Fan Tang, ${ }^{a, b}$ Honglong Xing, ${ }^{a}$ Huxiang Zheng, ${ }^{b}$ Lianhua Bi ${ }^{b}$ and Wei Wang $*, b$ \\ ${ }^{a}$ School of Chemical Engineering, Anhui University of Science and Technology, \\ Huainan, 232001, P. R. China \\ ${ }^{b}$ Key Laboratory for Advanced Technology in Environmental Protection of Jiangsu Province, \\ School of Chemical and biological Engineering, Yancheng Institute of Technology, \\ Yancheng, 224051, P. R. China
}

\begin{abstract}
Tiras de papel de filtro combinadas com eletrodos de carbono impresso (SPCE) foram usadas na montagem de um dispositivo microfluídico para detecção de $\mathrm{Pb}(\mathrm{II})$ and $\mathrm{Cd}(\mathrm{II})$ em soluções aquosas. O dispositivo microfluídico portátil (com detecção eletroquímica direta) foi testado na quantificação direta de analitos $(\mathrm{Pb}(\mathrm{II})$ e $\mathrm{Cd}(\mathrm{II}))$ em amostras aquosas contaminadas sem pré-tratamentos. $\mathrm{O}$ sinal voltamétrico de redissolução anódica de onda quadrada (SWASV) foi bastante intensificado e apresentou excelente desempenho analítico na detecção de $\mathrm{Pb}(\mathrm{II})$ e $\mathrm{Cd}$ (II) (de 0 a 100 ppb) com baixo limite de detecção (2,0 e 2,3 ppb, respectivamente). Os dispositivos eletroquímicos propostos também apresentaram boa seletividade e estabilidade para análises de amostras reais de refrigerante e água subterrânea com contaminação física. O dispositivo é simples, de baixo custo, fácil fabricação e portátel. Este dispositivo analítico tem a possibilidade de ser útil em aplicações do tipo point-of-care no monitoramento ambiental, na saúde pública e na segurança alimentar.
\end{abstract}

Filter paper strips combined with screen-printed carbon electrodes (SPCE) were used in the assembly of a microfluidic device for detecting $\mathrm{Pb}(\mathrm{II})$ and $\mathrm{Cd}$ (II) in aqueous samples. The portable microfluidic device (with direct electrochemical detection) was tested for direct quantification of multiple analytes $(\mathrm{Pb}(\mathrm{II})$ and $\mathrm{Cd}(\mathrm{II})$ ) in contaminated aqueous samples without pretreatment. Square wave anodic stripping voltammetric (SWASV) signal was greatly enhanced and displayed excellent analytical performance for $\mathrm{Pb}$ (II) and $\mathrm{Cd}$ (II) detection (from 0 to $100 \mathrm{ppb}$ ) with low limit of detection of 2.0 and $2.3 \mathrm{ppb}$, respectively. The proposed electrochemical devices also exhibited good selectivity and stability for analyses of real samples of gas dissolved salty soda water and ground water with physical contamination. The device is simple, low-cost, easy-to-fabricate and portable. This analytical device has the possibility of being useful for point-of-care applications in environmental monitoring, public health and food safety.

Keywords: microfluidic devices, screen-printed carbon electrodes, filter paper strip, portable device

\section{Introduction}

Analytical instrumentations tend to be miniaturization and intellectualization for in situ applications. ${ }^{1-4}$ Therefore, it can be convenient for real-time and on-line monitoring in the fields of environmental monitoring, biomedical science, agriculture, military analysis and industrial process monitoring, etc. Paper represents a great and useful supporting material for developing sensing devices owing to its various unique advantages, such as inexpensive, easy-printed, biodegradable and the porous structure

*e-mail: wangw@ycit.edu.cn facilitates lateral-flow assays suitable for chromatographic separations and as good filter. ${ }^{5-8}$ Screen-printing technology can be easily applied to the mass production of inexpensive, reproducible and sensitive disposable electrodes. ${ }^{9,10}$ Paper-based micro-electrochemical device integrated screen-printed carbon electrodes (SPCE) can meet the requirements for on-site monitoring of trace heavy metals. ${ }^{11-15}$

Currently, Martinez et al. ${ }^{16}$ reported many meaningful works on paper-based devices. A simple method was proposed for patterning paper to create well-defined and millimeter-sized channels for simultaneous detection of glucose and protein in urine. The use of a modified x,y-plotter was described to generate hydrophilic channels by printing 
a solution of hydrophobic polymer (poly(dimethylsiloxane, PDMS) dissolved in hexane onto filter paper, this low-cost system for printing hydrophobic polymers and other materials on paper would be useful for prototyping simple paper-based diagnostic assays. ${ }^{17}$ Fabrication of microfluidic paper-based electrochemical sensing devices ( $\mu$ PEDs) was introduced, $\mu$ PEDs comprised paper-based microfluidic channels patterned by photolithography or wax printing, and electrodes screen-printed on chromatography paper from conducting inks (e.g., carbon or $\mathrm{Ag} / \mathrm{AgCl}$ ). Using $\mu$ PEDs, they demonstrated the detection and quantification of glucose in artificial urine by chronoamperometric analysis based on glucose oxidase. They further demonstrated the use of $\mu \mathrm{PEDs}$ for analysis of $\mathrm{Pb}$ (II) in an aqueous solution..$^{18}$ Paper-based separation device was applied for the separation and quantification of uric and ascorbic acid. ${ }^{19}$ Our group exploited the advantage of filter paper to develop a paper disk impregnated with reagents on SPCE for a trace metal assay, $\mathrm{Pb}$ (II) could be measured with one-step method based on internal standard. ${ }^{11,12}$ Paper-based integration created a multifunctional device that can be applied in point-of-care testing in environmental or industrial monitoring of different analytes. ${ }^{17,20,21}$

Real samples always need to be pretreated before electrochemical detection because the signal in electrode is easily disturbed by physical factors such as bubble and contaminants. At this point, we describe a design of strips of filter paper integrated commercial SPCE for electrochemical detection of $\mathrm{Pb}$ (II) and $\mathrm{Cd}$ (II) in aqueous samples. Filter paper is tailored to a strip covered on SPCE as microfluidic carrier and filter medium, aqueous solution continuously flows along the paper and across the SPCE surface, and the bubble and contaminants are filtrated. Simultaneous detection of trace $\mathrm{Pb}(\mathrm{II})$ and $\mathrm{Cd}(\mathrm{II})$ is performed by square wave anodic stripping voltammetry (SWASV) relying on in situ plating of bismuth film. ${ }^{22-24}$ The proposed electrochemical devices exhibited good selectivity and stability for real samples of salty soda water and dirty ground water. The method showed a potential application for electrochemical detection of multiple analytes without pretreatment in paper-based microfluidic device.

\section{Experimental}

\section{Materials and instrumentation}

All chemicals used for the preparation of stock and standard solutions were of analytical grade. Solutions containing $\mathrm{Pb}(\mathrm{II}), \mathrm{Cd}(\mathrm{II})$ and $\mathrm{Bi}(\mathrm{III})$ were prepared by diluting of the corresponding standard stock solutions $\left(10^{3} \mathrm{mg} \mathrm{L}^{-1}\right)$ prepared with $\mathrm{Pb}\left(\mathrm{NO}_{3}\right)_{2}, \mathrm{Cd}\left(\mathrm{NO}_{3}\right)_{2} 4 \mathrm{H}_{2} \mathrm{O}$ and
$\mathrm{Bi}\left(\mathrm{NO}_{3}\right)_{3} 5 \mathrm{H}_{2} \mathrm{O}$, respectively. Working solutions were prepared with ultrapure water. A volume of $0.1 \mathrm{~mol} \mathrm{~L}^{-1}$ acetate buffer $(\mathrm{pH} 4.5)$ solution (prepared with acetic acid and sodium acetate) was used as support electrolyte. Square wave anodic stripping voltammetric measurements were performed with a CHI Workstation (Shanghai Chenhua Instrument Company, Model 840C). Whatman filter paper No. 1 was obtained from Cole-Parmer (Vernon Hills, Illinois). Screen-printed carbon electrodes (SPCE) were obtained from Gwent group (Toraen, United Kingdom) and it was included a three-electrode configuration printed on the same strip. The strips had a $2 \mathrm{~mm}$ diameter disk screen-printed carbon working electrode, a carbon counter electrode and a silver pseudo-reference electrode.

\section{Design and fabrication of the devices}

Paper-based microfluidic device was assembled with commercial chromatography paper strip (Whatman filter paper No.1) covered on SPCE. The paper strip was carefully cut with ca. $8 \mathrm{~mm}$ in width and $10 \mathrm{~cm}$ in length. Commercial SPCE was assembled onto the homemade hydrophobic PMMA (poly(methyl methacrylate) platform with double-sided adhesive tapes. The paper strip was left on the SPCE surface exactly so as to fully cover the 3 -electrode screen printed working, counter and reference electrodes. The paper strip has good wettability properties allowing for good contact with SPCE because of surface tension properties of water on paper without the use of external adhesive tapes. Figure 1 shows a scheme.

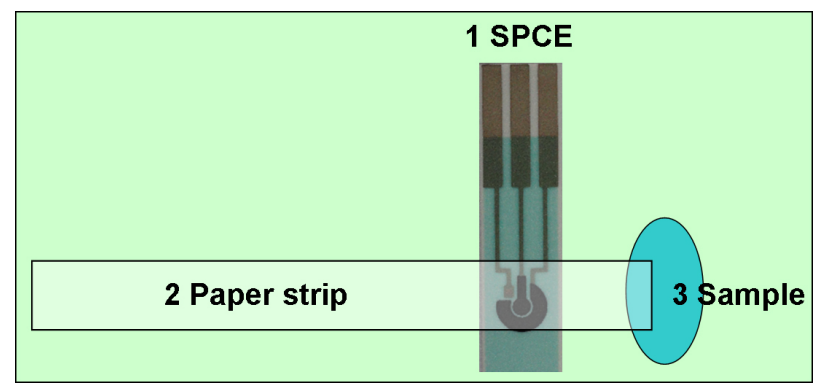

Figure 1. Scheme of a paper-based electrochemical sensing device. The sensor comprises (1) SPCE, (2) paper strip and (3) sample cell.

Square wave anodic stripping voltammetric measurements

Electrochemical analyses were performed by in situ deposition of $\mathrm{Bi}$ (III) $500 \mathrm{ppb}$, the Bi(III) solution was added to samples prior to electrodeposition. All measurements were carried out using the square wave anodic stripping voltammetry (SWASV) with a frequency of $20 \mathrm{~Hz}$, a potential step of $5 \mathrm{mV}$ and an amplitude of $25 \mathrm{mV}$. SWASV experiments comprised an electrochemical 
deposition step at $-1.4 \mathrm{~V}$ for $120 \mathrm{~s}$, an equilibration period of $30 \mathrm{~s}$ and a square-wave voltammetric stripping scan usually from -1.4 to $-0.4 \mathrm{~V}$. Before each measurement, a pre-conditioning step (for cleaning of the electrode) at a potential of $+0.5 \mathrm{~V}$ was applied for $60 \mathrm{~s}$.

\section{Results and Discussion}

\section{Design of the paper-based microfluidic device}

Currently, most chemical analyses are performed in modern laboratories equipped with expensive instruments and operated by highly qualified trained personnel. , 25,26 Now, the traditional chemical analysis cannot already satisfy the demand of the on-site test for the environment, food industry and so on. Therefore, a low-cost, single-use, easy-to-fabricate and portable device urgently need to be developed. ${ }^{6,26}$ Conventional approaches are usually performed either by dipping electrodes in a sample solution under controlled stirring condition or by placing a sample droplet onto the electrodes, ${ }^{27-29}$ and the samples with physical contaminants must be filtrated with additional off-line operations. For a point-of-care device, an ideal application is to provide a direct answer for an analysis with only a simple original sample introduction. Popular Whatman No. 1 chromatography paper is applied in our work because it is a clean paper, made of pure cellulose, and has relatively uniform thickness and wicking properties. ${ }^{5,30}$ As a result of commercial SPCE and simple and low-cost filter paper for one-step sensing, ${ }^{11}$ the idea of paper-based microfluidic devices for trace metal assay in physical contaminated aqueous samples came up from our group.

The design is shown in Figure 1, one end of the paper strip is dipped in the sample, the aqueous solution continuously flows along the paper and across the SPCE surface. The device processes three advantages: (i) physical contaminants such as unsolved particulates in the sample that still stay in the sample cell will not foul the electrode, (ii) dissolved gas in aqueous sample will not form as bubbles and adsorb on the electrode surface, and (iii) aqueous solution continuously flows along the paper and across the SPCE surface because of capillary force, the fresh sample solution will be kept on the electrode surface without manual stirring. These advantages quietly meet the requirements of the point-of-care detection for original samples in the environmental monitoring and food analysis.

\section{Liquid movement in filter paper}

The flow of sample is driven by capillary action within pores of the paper. The imbibition in porous membranes was mathematically and experimentally studied by Mendez et al. ${ }^{31}$ In a porous membrane of constant crosssection, liquid moves according to Darcy's Law:

$\mu_{s}=\frac{\kappa_{s} \Delta P}{\mu L_{c}}$

where $\mu_{s}$ is the superficial fluid velocity, $\kappa_{s}$ is the superficial permeability of the porous medium, $\Delta P$ is the pressure difference over the length $L_{c}$ of the liquid-filled region, and $\mu$ is the viscosity.

The driving force for imbibition is the capillary suction pressure $P_{c}$ given by the following equation:

$P_{c}=\frac{2 \gamma \cos \theta}{r_{m}}$

where $\gamma=$ surface tension, $\theta=$ contact angle of the liquid with the material and $r_{m}=$ mean pore radius. For porous media, the capillary pressure is established by the mean pore radius, which, in the case of the nitrocellulose membranes used here, is essentially constant along the paper strip. For the simplest one-dimensional model of a porous rectangular strip, it is well-known that the wetted area covers a distance $l(t)$ :

$l(t)=2 \sqrt{\frac{k_{s} \gamma \cos \theta}{\phi \mu r_{m}}} \sqrt{t}$

where $\phi$ is porosity of the material and $l(0)=0, \cos \theta=1$. This result is known as the Lucas-Washburn equation. It predicts that flow velocity diminishes with the increase of the time.

In the research, it was kept the distance between SPCE and sample as $3 \mathrm{~cm}$, the electrochemical analysis was started when SPCE was all immersed in aqueous solution. The flow distance was about $7 \mathrm{~cm}$ untill the end of the experiments, a section of the paper was also kept dry for driving the solution. The sample consumption in the analysis was about $100 \mu \mathrm{L}$ by quantifying the volume of solution in the sample cell before and after the experiment.

Validation of paper-based microfluidic device for simultaneous detection of $\mathrm{Pb}(\mathrm{II})$ and $\mathrm{Cd}(\mathrm{II})$

Literature reported that carbon electrodes with a bismuth layer dramatically improved its ability to detect trace $\mathrm{Pb}$ (II) and $\mathrm{Cd}$ (II) based on the simultaneous (in situ) plating of $\mathrm{Bi}(\mathrm{III})$ and heavy metals onto SPCE. ${ }^{32,33}$ In the present work, the sensitivity of electrochemical detection was higher in the paper-based microfluidic devices in comparison with placing a sample droplet onto 
the electrodes. The results are shown in Figure 2, the voltammograms for $50 \mathrm{ppb} \mathrm{Pb}$ (II) and $\mathrm{Cd}(\mathrm{II})$ in the static system (a sample droplet is placed onto the electrodes) (Figure 2b) and dynamic system (a sample solution flows in the paper-based microfluidic device) (Figure 2a) displayed a defined response of $\mathrm{Pb}$ and $\mathrm{Cd}$ with peaks at ca. 826 and $1042 \mathrm{mV}$ vs. the $\mathrm{Ag} / \mathrm{AgCl}$ reference electrode, respectively, and the dynamic system (Figure 2a) exhibited a much higher sensitivity than the static system (Figure 2b). It was considered that the enhanced sensitivity of dynamic system is related to the high efficiency of accumulation of heavy-metals on the electrode surface by convection of flowing fluids in the porous matrix of the paper.

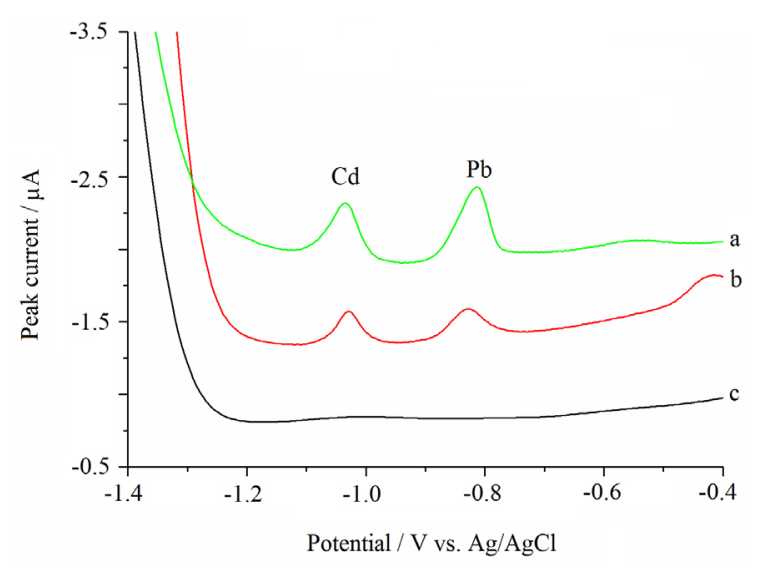

Figure 2. SWASV voltammograms for $50 \mathrm{ppb} \mathrm{Pb}(\mathrm{II})$ and $\mathrm{Cd}(\mathrm{II})$ in $0.1 \mathrm{~mol} \mathrm{~L}^{-1}$ acetate buffer $(\mathrm{pH} 4.5)$ in the presence of $500 \mathrm{ppb} \mathrm{Bi}(\mathrm{III})$ : a solution of analytes continuously wicking the filter paper channel of the paper-based microfluidic devices across the surface of SPCE (a); a $50 \mu \mathrm{L} 50 \mathrm{ppb}$ solution of $\mathrm{Pb}(\mathrm{II})$ and $\mathrm{Cd}(\mathrm{II})$ directly placed on the electrode without strips of the filter paper (b); a solution of blank samples $\left(0.1 \mathrm{~mol} \mathrm{~L}^{-1}\right.$ acetate buffer ( $\left.\mathrm{pH} 4.5\right)$ without $\mathrm{Pb}$ (II) and $\left.\mathrm{Cd}(\mathrm{II})\right)$ continuously wicking the filter paper of the paper-based microfluidic devices across the surface of SPCE (c). SWASV was performed in the potential range of -1.40 to $-0.40 \mathrm{~V}$ under optimized conditions: frequency of $20 \mathrm{~Hz}$, amplitude of $25 \mathrm{mV}$, potential increment of $5 \mathrm{mV}$, equilibration time of $30 \mathrm{~s}$. Deposition is performed at $-1.40 \mathrm{~V}$ for $120 \mathrm{~s}$, and electrode preconditioning is performed at $+0.50 \mathrm{~V}$ for $60 \mathrm{~s}$. Bi(III) concentration of $500 \mathrm{ppb}$ was chosen for the codeposition of heavy-metal ions.

In the paper-based microfluidic system, the peak current increased with the increase of the deposition time. Figure 3 exhibits stripping voltammograms for the measurement of $50 \mathrm{ppb} \mathrm{Pb}(\mathrm{II})$ and $\mathrm{Cd}(\mathrm{II})$ in $0.1 \mathrm{~mol} \mathrm{~L}^{-1}$ acetate buffer ( $\mathrm{pH} 4.5$ ) in the dynamic system by adjusting the deposition time from 60 to $360 \mathrm{~s}$. The peak currents of the measurements for $\mathrm{Pb}(\mathrm{II})$ and $\mathrm{Cd}(\mathrm{II})$ dramatically increase with the increase of the time deposition. The reason is that the longer deposition time was applied, the larger amount of heavy metals was deposited on the electrode surface.

The voltammograms showed a well-defined, sharp peak when low levels of heavy-metal ions were detected in the paper-based microfluidic devices. SWASV voltammograms

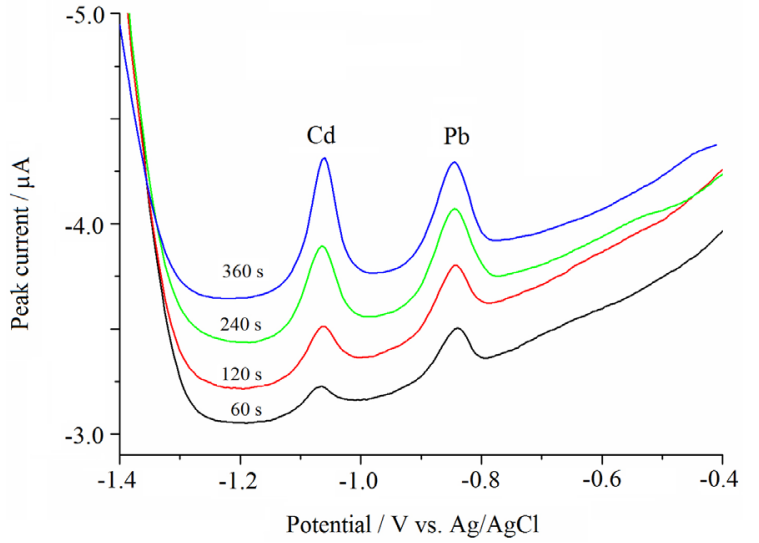

Figure 3. SWASV voltammograms for $50 \mathrm{ppb} \mathrm{Pb}(\mathrm{II})$ and $\mathrm{Cd}(\mathrm{II})$ in $0.1 \mathrm{~mol} \mathrm{~L}^{-1}$ acetate buffer ( $\left.\mathrm{pH} 4.5\right)$ in the presence of $500 \mathrm{ppb} \mathrm{Bi}$ (III) with variable deposition times from 60 to $360 \mathrm{~s}$ on strips of the filter paper integrated SPCE. Other SWASV experimental details are as in Figure 2.

are shown in Figure 4. The concentration of $10 \mathrm{ppb}$ of $\mathrm{Pb}$ (II) and $\mathrm{Cd}(\mathrm{II})$ was tested with SWASV method in the proposed device, this amount is the WHO (World Health Organization) guideline value for $\mathrm{Pb}(\mathrm{II})$ and $\mathrm{Cd}(\mathrm{II})$ concentration in drinking water. ${ }^{34}$ Figure $4 \mathrm{a}$ shows $10 \mathrm{ppb}$ of $\mathrm{Pb}$ (II) and $\mathrm{Cd}(\mathrm{II})$ responded in the paper-based microfluidic device. The signals are strong, but the same concentration (10 ppb) of $\mathrm{Pb}(\mathrm{II})$ and $\mathrm{Cd}(\mathrm{II})$ in static system for deposition time of $360 \mathrm{~s}$ displayed weak response (Figure $4 \mathrm{~b}$ ) and no response is observed for deposition of $120 \mathrm{~s}$ (Figure 4c).

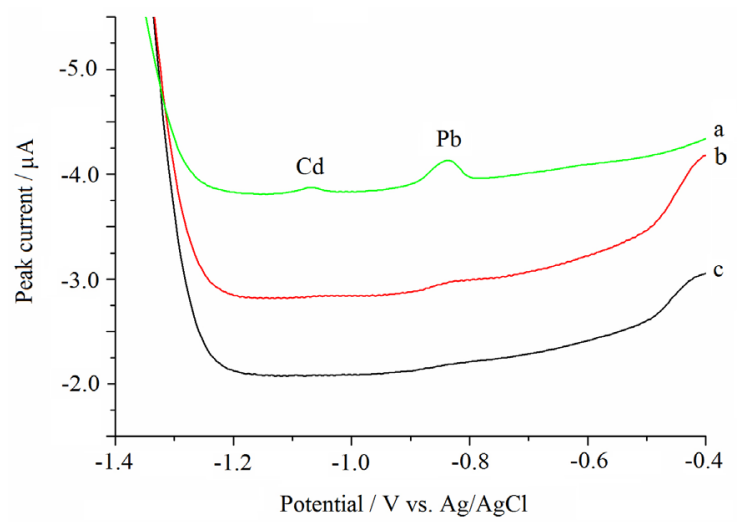

Figure 4. SWASV voltammograms for $10 \mathrm{ppb}$ solution of $\mathrm{Pb}$ (II) and $\mathrm{Cd}(\mathrm{II})$ in $0.1 \mathrm{~mol} \mathrm{~L}^{-1}$ acetate buffer ( $\mathrm{pH} 4.5$ ) in the presence of $500 \mathrm{ppb} \mathrm{Bi}(\mathrm{III})$ in the paper-based microfluidic device for $120 \mathrm{~s}$ deposition (a), a $50 \mu \mathrm{L}$ $10 \mathrm{ppb}$ solution of $\mathrm{Pb}(\mathrm{II})$ and $\mathrm{Cd}$ (II) directly placed on the electrode without strips of the filter paper for $360 \mathrm{~s} \mathrm{(b)} \mathrm{and} 120 \mathrm{~s}$ (c). Other SWASV experimental details are as in Figure 2.

The stripping voltammograms for the analysis of $\mathrm{Pb}$ (II) and $\mathrm{Cd}(\mathrm{II})$ in the paper-based microfluidic devices showed well-defined peaks and strong signals over a range of 10 and $100 \mathrm{ppb}$ (Figure 5a). The peak intensity increased proportionally with the concentration, which yielded a highly linear calibration plot with a slope of $8.95 \mathrm{nA} \mathrm{ppb}^{-1}$ for $\mathrm{Pb}$ (II) (correlation coefficient 
of 0.99832 ) and $10.53 \mathrm{nA} \mathrm{ppb}^{-1}$ for Cd(II) (correlation coefficient of 0.99856) (Figure 5b). The limit of detection of $\mathrm{Pb}$ (II) and $\mathrm{Cd}(\mathrm{II})$ (defined as the average blank value plus 3 times the value of the standard deviation of the blank value) was estimated to be approximately 2.0 and $2.3 \mathrm{ppb}$ in combination with deposition time of $120 \mathrm{~s}$, this value is even lower than $2.5 \mathrm{ppb}$ obtained in conventional systems with controlled stirring..$^{27,28,35-37}$ This is also much lower than the $10 \mathrm{ppb}$ World Health Organization (WHO) guideline value for $\mathrm{Pb}(\mathrm{II})$ and $\mathrm{Cd}(\mathrm{II})$ concentration in drinking water. ${ }^{37}$ The electrochemical detection of $\mathrm{Pb}(\mathrm{II})$ and $\mathrm{Cd}(\mathrm{II})$ in the paper-based microfluidic devices was also highly reproducible, presenting relative standard deviations (RSD) of 3.6 and $4.3 \%$ for $\mathrm{Pb}$ and $\mathrm{Cd}$, respectively, analyses obtained from six repetitive measurements.

(a)

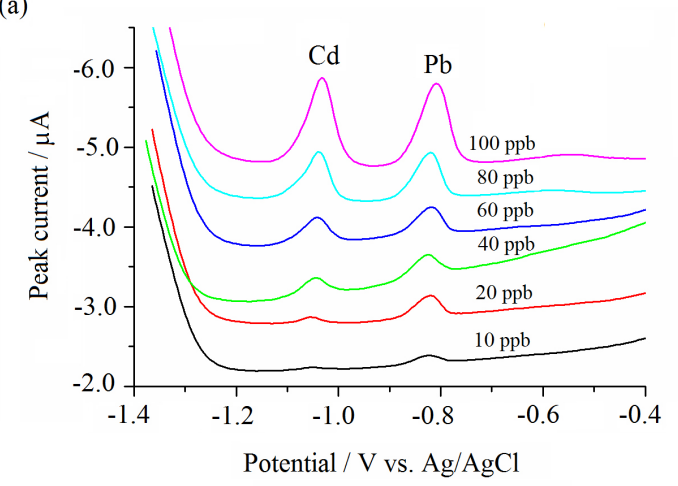

(b)

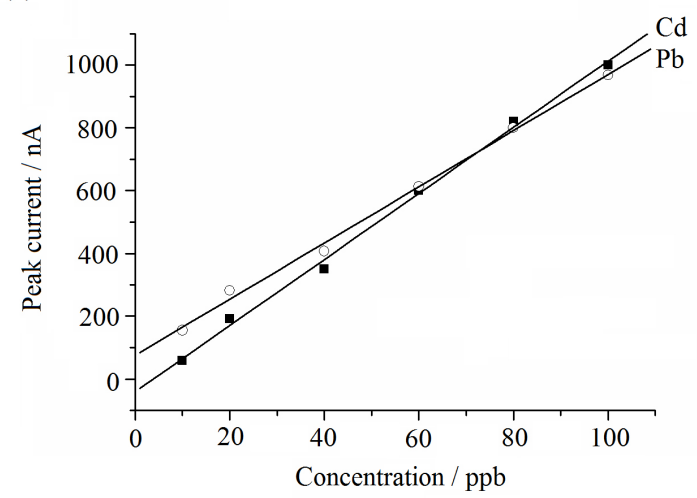

Figure 5. SWASV voltammograms for the simultaneous analysis of trace $\mathrm{Pb}(\mathrm{II})$ and $\mathrm{Cd}$ (II) in the presence of $\mathrm{Bi}(\mathrm{III})$ in the paper-based microfluidic devices. The concentrations of $\mathrm{Pb}$ (II) (ascending along the $\mathrm{y}$-axis) are 10 , 20, 40, 60, 80 and $100 \mathrm{ppb}$. The data are unsmoothed (a). The resulting calibration plots for trace $\mathrm{Pb}(\mathrm{II})(\mathrm{O})$ and $\mathrm{Cd}(\mathrm{II})$ (घ) from 10 to $100 \mathrm{ppb}$ (b). Other SWASV experimental details are as in Figure 2.

Lower limits of detection can be expected by using correspondingly prolonged deposition time. In this assay, small volume (ca. $100 \mu \mathrm{L}$ for deposition time of $120 \mathrm{~s}$ ) of sample solution was consumed throughout electrochemical detection of $\mathrm{Pb}(\mathrm{II})$ and $\mathrm{Cd}(\mathrm{II})$ in the paper-based microfluidic devices.
Detection of $\mathrm{Pb}(\mathrm{II})$ and $\mathrm{Cd}(\mathrm{II})$ in salty soda water and dirty ground water

According to the original purpose of the device, commercial salty soda water and dirty ground water were applied as model samples for the detection of $\mathrm{Pb}$ (II) and $\mathrm{Cd}(\mathrm{II})$. Commercial salty soda water is carbonic acid beverage, contains carbonic acid, and the dissolved gas will be adsorbed on the electrode surface with traditional method. The stripping voltammograms for commercial salty soda water spiked with $10 \mathrm{ppb} \mathrm{Pb}$ (II) and $\mathrm{Cd}(\mathrm{II})$ are shown in Figure 6. Dirty ground water was obtained from a pond in Yancheng countryside (P. R. China). The water contains physical contaminates that will affect the electrochemical detection if un-pretreated sample is introduced. The stripping voltammograms for dirty ground water spiked with $10 \mathrm{ppb} \mathrm{Pb}(\mathrm{II})$ and $\mathrm{Cd}(\mathrm{II})$ are shown in Figure 7. From the

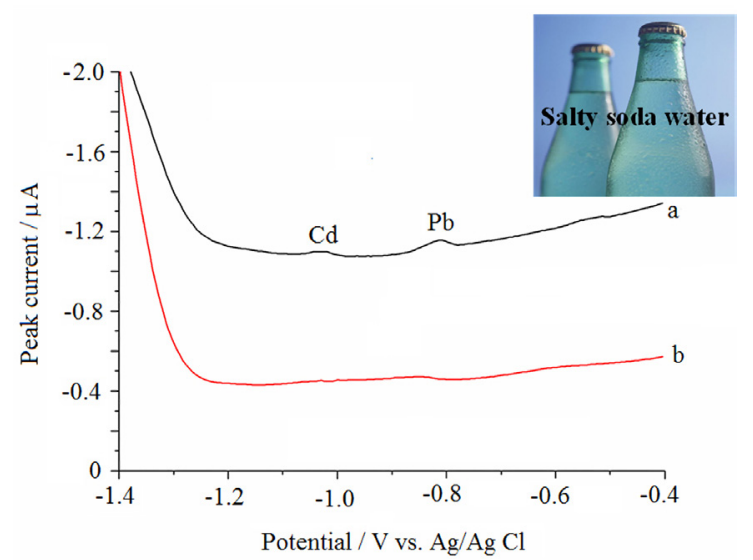

Figure 6. SWASV voltammograms in the paper-based microfluidic device for real sample of commercial salty soda water in $0.1 \mathrm{~mol} \mathrm{~L}^{-1}$ acetate buffer ( $\mathrm{pH} 4.5)$ in the presence of $500 \mathrm{ppb} \mathrm{Bi}(\mathrm{III}), 10 \mathrm{ppb} \mathrm{Pb}(\mathrm{II})$ and $\mathrm{Cd}(\mathrm{II})$ were spiked in the sample (a), and without heavy metals spiked (b). Other SWASV experimental details are as in Figure 2.

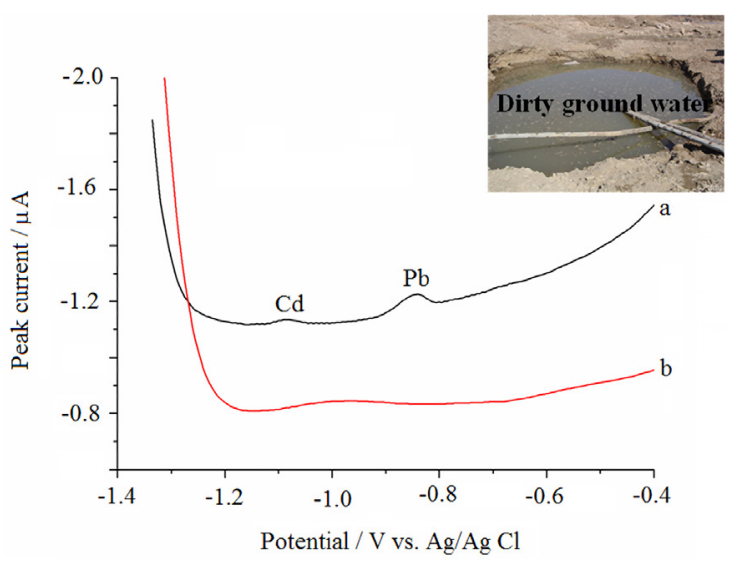

Figure 7. SWASV voltammograms in the paper-based microfluidic device for real sample of dirty ground water in $0.1 \mathrm{~mol} \mathrm{~L}^{-1}$ acetate buffer $(\mathrm{pH} 4.5)$ in the presence of $500 \mathrm{ppb} \mathrm{Bi}(\mathrm{III}), 10 \mathrm{ppb} \mathrm{Pb}$ (II) and $\mathrm{Cd}(\mathrm{II})$ are spiked in the sample (a), and without heavy metals spiked (b). Other SWASV experimental details are as in Figure 2. 
voltammograms, it was possible to conclude the that paperbased microfluidic device is suitable for simultaneous detection of $\mathrm{Pb}(\mathrm{II})$ and $\mathrm{Cd}(\mathrm{II})$ in salty soda water and dirty ground water. The results are list in Table 1.

Table 1. Determinationa of $\mathrm{Pb}(\mathrm{II})$ and $\mathrm{Cd}(\mathrm{II})$ in water samples with paperbased microfluidic device

\begin{tabular}{lcc}
\hline Real samples & $\begin{array}{c}\mathrm{Pb}(\mathrm{II}) / \mathrm{Cd}(\mathrm{II}) \\
\text { added / ppb }\end{array}$ & $\begin{array}{c}\mathrm{Pb}(\mathrm{II}) / \mathrm{Cd}(\mathrm{II}) \text { found }^{\mathrm{a}} \\
\text { with proposed } \\
\text { method / ppb }\end{array}$ \\
\hline Salty soda water (1) & $50 / 50$ & $49.7 \pm 6.5 / 50.8 \pm 5.3$ \\
Salty soda water (2) & $10 / 10$ & $10.9 \pm 2.9 / 10.1 \pm 1.8$ \\
Salty soda water (3) & $0 / 0$ & no detection \\
Dirty ground water (1) & $50 / 50$ & $51.0 \pm 7.2 / 49.6 \pm 3.1$ \\
Dirty ground water (2) & $10 / 10$ & $9.7 \pm 2.4 / 11.1 \pm 2.0$ \\
Dirty ground water (3) & $0 / 0$ & no detection \\
\hline
\end{tabular}

${ }^{a}$ Six repetitive measurements, mean value \pm expanded uncertainty.

\section{Conclusions}

It was demonstrated here the detection of ppb levels of $\mathrm{Pb}$ (II) and $\mathrm{Cd}$ (II) in salty soda water and dirty ground water with paper-based microfluidic device. Based on the paper-based microfluidic device, original samples of gas dissolved and physical contaminated water can be directly applied for electrochemical measurements. When the sample solution flows along the filter paper and across the surface of SPCE by the continuous capillary wicking of fluids, it provides a thin mechanically stabilized film of water or other fluids on the surface of SPCE and delivers fresh sample for analysis. Because the device is low-cost, small sample consumed and easy operated, this practical application of paper-based microfluidic device shows a good prospect for further miniaturization and intellectualization in the field of medical health, food safety and environmental monitoring.

\section{Acknowledgements}

We greatly appreciate the financial support of National Natural Science Foundation of China (20875080), Foundation of International Cooperation of Jiangsu Province (BZ2010053), Foundation of Key Laboratory for Advanced Technology in Environmental Protection of Jiangsu Province (AE201017), and Scientific Project of Yancheng Institute of Technology (XKY2009010, XKY2009016).

\section{References}

1. Prasek, J.; Adamek, M.; Hubalek, J.; Adam, V.; Trnkova, L.; Kizek, R.; Sensors 2006, 6, 1498.

2. Whitesides, G. M.; Nature 2006, 442, 368.
3. Gardeniers, J. G. E.; van den Berg, A.; Anal. Bioanal. Chem. 2004, 378, 1700.

4. Crevillen, A. G.; Hervas, M.; Lopez, M. A.; Gonzalez, M. C.; Escarpa, A.; Talanta 2007, 74, 342.

5. Martinez, A. W.; Phillips, S. T.; Whitesides, G. M.; Anal. Chem. 2010, 82,3 .

6. Pelton, R.; TrAC, Trends Anal. Chem. 2009, 28, 925.

7. Zhao, W.; Ven den Berg, A.; Lab Chip 2008, 8, 1988.

8. Martinez, A. W.; Phillips, C. E.; Thomas III, S. W.; Sindi, H.; Whitesides, G. M.; Anal. Chem. 2008, 80, 3699.

9. http://www.dropsens.com accessed in September 2011.

10. http://www.gwent.org/Gem/index.html accessed in September 2011.

11. Tan, S. N.; Ge, L.; Wang, W.; Anal. Chem. 2010, 82, 8844.

12. Fang, H. L.; Zheng, H. X.; Ou, M. Y.; Meng, Q.; Fan, D. H.; Wang, W.; Sens. Actuators, B 2011, 153, 369.

13. Mamani, M. C. V.; Aleixo, L. M.; Abreu, M. F.; Rath, S.; J. Pharm. Biomed. Anal. 2005, 37, 709.

14. Senthilkumar, S.; Saraswathi, R.; Sens. Actuators, B 2009, 141, 65.

15. Jakmunee ,J.; Junsomboon, J.; Talanta 2008, 77, 172.

16. Martinez, A. W.; Phillips, S. T.; Butte, M. J.; Whitesides, G. M.; Angew. Chem., Int. Ed. 2007, 46, 1318.

17. Bruzewicz, D. A.; Reches, M.; Whitesides, G. M.; Anal. Chem. 2008, 80, 3387.

18. Nie, Z.; Nijhuis, C. A.; Gong, J.; Chen, X.; Kumachev, A.; Martinez, A. W.; Narovlyansky, M.; Whitesides, G. M.; Lab Chip 2010, 10, 477.

19. Carvalhal, R. F.; Kfouri, M. S.; de Oliveira Piazetta, M. H.; Gobbi, A. L.; Kubota, L. T.; Anal. Chem. 2010, 82, 1162.

20. Li, X.; Tian, J.; Nguyen, T.; Shen, W.; Anal. Chem. 2008, 80, 9131.

21. Martinez, A.W.; Phillips, S.T.; Wiley, B.J.; Gupta, M.; Whitesides, G.M.; Lab Chip 2008, 8, 2146.

22. Hocevar, S. B.; Ogorevc, B.; Wang, J.; Pihlar, B.; Electroanalysis 2002, 14, 1707.

23. Kefala, G.; Economou, A.; Talanta 2003, 61, 603.

24. Castañeda, M. T.; Pérez, B.; Pumera, M.; del Valle, M.; Merkoçi, A.; Alegret, S.; Analyst 2005, 130, 971.

25. Mabey, D.; Peeling, R. W.; Ustianowski, A.; Perkins, M. D.; Nat. Rev. Microbiol. 2004, 2, 231.

26. Yager, P.; Edwards, T.; Fu, E.; Helton, K.; Nelson, K.; Tam, M. R.; Weigl, B. H.; Nature 2006, 442, 412.

27. Rico, M. A. G.; Olivares-Marin, M.; Gil, E. P.; Electroanalysis 2008, 20, 2608.

28. Honeychurch, K. C.; Hart, J. P.; TrAC, Trends Anal. Chem. 2003, 22, 456.

29. Kadara, R. O.; Tothill, I. E.; Anal. Bioanal. Chem. 2004, 378, 770.

30. Zhao, W.; Ali, M. M.; Aguirre, S. D.; Brook, M. A.; Li, Y.; Anal. Chem. 2008, 80, 8431. 
31. Mendez, S.; Fenton, E. M.; Gallegos, G. R.; Petsev, D. N.; Sibbett, S. S.; Stone, H. A.; Zhang, Y.; Lopez, G. P.; Langmuir 2010, 26, 1380.

32. Li, J.; Zhang, J.; Wei, H.; Wang, E.; Analyst 2009, 134, 273.

33. Rico, M. A. G.; Olivares-Marin, M.; Gil, E. P.; Talanta 2009, 80,631 .

34. World Health Organization (WHO); Guidelines for DrinkingWater Quality; WHO Press: Geneva, Switzerland, 2006.
35. Wang, J.; Lu, J.M.; Hoceva, S. B.; Farias, P. A. M.; Ogorevc, B.; Anal. Chem. 2000, 72, 3218.

36. Hwang, G. H.; Han, W. K.; Park, J. S.; Kang, S. G.; Sens. Actuators, B 2008, 135, 309.

37. Wang, J.; Lu, J. M.; Kirgoz, U. A.; Hocevar, S. B.; Ogorevc, B.; Anal. Chim. Acta 2001, 434, 29.

Submitted: February 7, 2012

Published online: May 24, 2012 